\title{
On Integrated Teaching of Hotel Management Specialty
}

\author{
Zhi Zhang \\ Hotel Management College, Wuhan City Vocational College, Wuhan, 430064, China
}

Keywords: Hotel management, Integrated, Teaching

\begin{abstract}
In the era of internationalization, Chinese hotel industry has become a representative window of economy and culture etc. Meanwhile, it also embodies comprehensive national strength. So, the state places greater expectations on hotel industry. Hotel management specialty as hotel talent delivery channel should accurately master the demand of hotel industry and national economic development and reform talent training mode. Integrated teaching mode which combines theory and practice is an efficient teaching mode which can effectively resolve hotel education problems.
\end{abstract}

\section{Introduction}

As China's economic development still further tends to globalization, Chinese hotel industry has accelerated development speed in recent years. The state pays sufficient attention to hotel industry to guarantee competitiveness of hotel industry in international economy market. Hotel management specialty serves as a major window to provide talents foe hotel industry. Although as hotel management specialty goes deep, hotel management specialty has achieved certain progress in recent years, many problems still appear. Thus, theoretical knowledge is disconnected with practical work. Integrated teaching emerges to solve such problem. Next, this paper discusses the problems existing in current hotel education in China and specific measures of integrated teaching, hoping to provide more rational reference for talent training in hotel management specialty and development of hotel industry.

\section{Existing problems of hotel education in China}

\section{Teaching methods are old-fashioned.}

At present, hotel management specialty of most colleges still adopt traditional teaching mode. Teachers give lessons, while students purely observe and make records. The proportion of practical training is insufficiently seriously. The leasing role of students cannot stand out. Naturally, they cannot gain better learning effect. Obviously, such teaching method is harmful to both hotel talent training and future development of hotel majors.

\section{Teaching content is disconnected with actual market demand.}

Most teaching materials of hotel management specialty are uniformly prepared by the state. The contents fail to update according to real-time market demand and actual conditions. Thus, theoretical knowledge students learn is not all-round enough, and do not comply with actual situations of hotel industry, either. Students' knowledge hierarchy is out-dated, so naturally they cannot accord with the demand of hotel industry and national economic development ${ }^{[1]}$.

\section{Students' occupational cognition is insufficient.}

Hotel industry in China has become a focus industry, and the employment prospect is relatively good. Even so, college students generally consider hotel industry does not need any professional quality. Besides, social pays insufficient attention to this industry, so students have no clear objective and even give up halfway. As well, turnover rate is high. Students fail to fully cognize actual conditions of hotel specialty. All impose serious impacts on follow-up development of hotel majors and future student enrollment.

\section{Quality of teaching team is insufficient.}

Currently, teaching team in charge of hotel specialty teaching consists of teachers with rich theoretical knowledge. There are few teachers with both sufficient theoretical and practical knowledge. The teachers with rich theoretical knowledge generally lack practical hotel work 
experience, while some teachers with abundant practical experience lack theoretical knowledge. Thus, the overall quality of teaching team cannot be balanced. In actual teaching process, teachers are the guides who lead students to enter hotel industry step by step. Hence, teachers' ability represents students' learning effect. Therefore, if teachers' comprehensive quality is insufficient, teaching quality cannot be really improved.

\section{Approaches to implement integrated teaching for hotel management specialty}

\section{To enhance classroom effect in combination of practical situation.}

Course contents of hotel management specialty are prepared in allusion to practical hotel work, so it is difficult for students to understand and digest them only through verbal teaching. Thus in teaching process, teachers need to apply teaching situation to stimulate students' imagination and let students further connect theory with practice. For example, when teaching hotel etiquette, teachers may create virtual hotel environment through pictures, video and audio and act as customers to assist students in practicing standard phrases in receiving, booking and compliant handling links. Through situation creation, students can further experience actual hotel work atmosphere and fast improve their skills in such atmosphere. Students' actual working ability can improve through feeling actual work atmosphere in classroom ${ }^{[2]}$.

To attach importance to practical training link and reinforce fusion of theory and practice.

Students learn at school in order to lay a solid foundation for future hotel work. So, only when they know actual work of hotel industry can they give play to theoretical knowledge. Therefore, practical training link is the most important link in hotel specialty education. After new students enter colleges, colleges should contact internship units as soon as possible and organize them to observe and intern at regular intervals so that they can preliminarily understand future industry, post, job content and requirements. During implementing theoretical education, students are required to participate in actual hotel work as soon as possible and gradually adapt hotel theoretical education and job requirements. At weekends or during vacations, students should practice at hotels so as to more deeply understand actual hotel work, learn the skills to solve various problems, further improve their specialty accomplishment, practical working ability and problem solving ability. Besides, students should participate in internship during the college, which contributes to their future post positioning and formulation of learning plan. When students understand each post and actual job requirements, they can set their learning and employment plan.

\section{To intensity course setting and improve teaching effect.}

Theoretical courses decide students' final knowledge reserve and theory application ability, so it is urgent to solve the disconnection between hotel course contents and actual work. The various demands in hotel industry are very detailed, and functions of each post are different. With era development, everything is changing. In recent years, more relevant posts have appeared in hotel industry. Thus, teaching contents of hotel specialty need reforming and setting according to era development and actual demand in order to ensure connection of hotel education and actual work ${ }^{[3]}$. Course setting should be done according to each work link and features of each post. For instance, reception desk of a hotel pays attention to language, deportment and observation ability etc. So, for reception desk post, hotel etiquette, standard hotel language and actual training contents should be provided. Meanwhile, the training for deportment, language, flexibility and problem handling ability should be enhanced. For switchboard telephone connection post, intensity of hotel language course should be enhanced, and complaint handling training should be increased. More detailed course setting in allusion to students' future employment panning and actual ability can make sure students better find out their post positioning after entering hotel industry.

\section{To introduce the latest hotel information and help students master the situation.}

The trend and information of an industry will certainly alter with market changes. Hotel industry is also the case. The development trend of hotel industry is ever-changing. As future talents of hotel industry, student majors must further understand the form of hotel industry and future trend so as to more accurately position their study and work. Therefore, colleges should not just cooperate with hotel enterprises in terns of practice and information, and introduce relevant industrial information in 
information library of colleges. The information may be internal magazines of hotel enterprises, or the latest working norms and talent requirements of hotel industry. With more explicit information, students can further know the industry and formulate their learning and working plans according to actual demands of hotel industry ${ }^{[4]}$.

To intensify education normalization and require students with hotel job requirements.

Habit cultivation is very significant. If students are very free and lax in discipline, with low quality, their long-term development cannot be endured even if classroom education is adopted. The employees in hotel industry need to own sharp observation ability, elegant deportment, clear and standard deportment and independent problem handling ability etc. These abilities are gradually cultivated through accumulation in daily study and life. So, colleges should not merely focus on classroom education, but also pay attention to cultivation of students' words and actions in life. For example, colleges may utilize ballet and yoga training to improve students' deportment, and improve their ideology and connotation through reading party and other activities. Only when students improve their knowledge accomplishment and value and competitiveness in hotel industry can they gain better development in hotel field.

\section{Matters needing attention during implementation of integrated teaching}

\section{To lay emphasis on connection with actual work.}

Teaching of hotel management specialty serves for hotel industry. Only when the knowledge students learn is connected with actual hotel work can it be practically applied to solve problems in actual work. Such education can be considered as effective hotel specialty education. No matter how education mode and teaching content of hotel management specialty improve, they must focus on actual hotel work and pay attention to actual demand and norms of hotel industry to ensure conformity to various requirements of hotel industry. Only in this way, the education in this state is effective and students' learning process is more effective ${ }^{[5]}$.

\section{To associate with real-time trend of the whole industry.}

Industrial trend decides reform and improvement direction of hotel specialty teaching. Thus, only when hotel specialty know real-time trend of hotel industry more deeply, teaching contents and modes can be planned and created in a better manner. Only when students have a deeper understanding of the trend of hotel industry can they correct and improve their employment plan and learning plan and guarantee their competitiveness in hotel industry. Hence, this is certainly one of hotel teaching emphases, and colleges should value this in order to practically promote teaching innovation and ensure development of hotel specialty teaching and hotel industry.

To lay emphasis on practice unit selection and practical training link management.

College education is certainly important. Many colleges will build their own hotel practice base for hotel specialty. But compared with college classroom education and training base, practical training units can really offer an authentic occupational experience environment for students. Practical training base is just for students in the college. Relative to real hotel working environment, such practical training has limitations. Through cooperation with hotels, students can really reach to employees and real customers. In this way, students can deepen understanding of hotel posts and various requirements, and improve problem solving ability and professional quality. Therefore, colleges need to pay more attention to selecting internship units, overall manage and supervise students' practice process and ensure normalization of practice process.

\section{To pay attention to teaching team building.}

"Integrated" teaching pays attention to fusion of theory and practice. So, double-position teachers are required. Double-position teachers refer to comprehensive teachers with rich theoretical knowledge and actual operation ability. Stricter and deeper training should be conducted for teaching team to make sure teachers can more flexibly adopt actual operation, demonstration teaching, brainstorming, subject task, multimedia teaching and case teaching to improve classroom atmosphere and teaching effect., 


\section{Conclusions}

China's hotel industry further tends to internalization, so the requirements for talents become increasingly high. Meanwhile, this industry gives wider and wider development platform for talents. Hence, education of hotel management specialty is faced with higher objectives and severer challenges. Only when colleges keep on improving education mode and teaching contents can they guarantee supply of more high-quality and high-ability talents for hotel industry. Integrated education is devoted to fusing theoretical knowledge with actual hotel work. It is an effective teaching measure to promote pertinence of talent training. If hotel specialty can better utilize integrated teaching, students' overall competence and knowledge accomplishment will certainly be improved to guarantee their development in hotel industry. Further, hotel industry can own stronger talent team and China’s hotel industry can improve competitiveness in international market.

\section{References}

[1] Sun Li, Several Thoughts on Integrated Teaching of Hotel Management Specialty. Hua Zhang, 2011(36):199.

[2] Lu Wei, Exploration of Integrated Teaching Reform of Hotel Management Specialty. China Juveniles (Study on Adolescent Education), 2013(19):249.

[3] Zhang Xiaoqiang, Study on Teaching Integration of Hotel Management Specialty in Vocational Colleges. Jilin Pictorial (Jiao Yu Bai Jia A), 2014(3):45-45.

[4] Luo Zhizhen, Gains on Integrated Teaching Reform of Hotel Management Specialty. Business, 2013(29):345-345.

[5] Zhang Yonggang, Exploration of Occupational Quality Cultivation Mode based on College-Enterprise Integrated Teaching--Case Study of "0+35" Pilot Class Education in Hotel Management Specialty. Journal of Vocational Institute of Commercial Technology, 2013,11(1):70-73. 